\title{
Synthesis and Performance of A Novel Penetration Enhancer
}

\author{
Qin WU \\ Department of Pharmacy \\ Hangzhou Children's Hospital \\ Hangzhou, China \\ e-mail: 260717721@qq.com \\ Haimin SHEN* \\ College of Chemical Engineering \\ Zhejiang University of Technology \\ Hangzhou, China \\ e-mail: haimshen@zjut.edu.cn
}

\author{
Lei TANG \\ Department of R\&D Centre \\ Astellas Phama Inc (China) \\ Shenyang, China \\ e-mail: wzmctanglei@163.com
}

\author{
Hongxin SHI \\ College of Chemical Engineering \\ Zhejiang University of Technology \\ Hangzhou, China \\ e-mail: shihxin@zjut.edu.cn
}

\begin{abstract}
Preparation and percutaneous absorption of 2-methyl2-perfluoro-2'-methyl-3'-oxoca-proyloxyl ethoxycarbonyl ethylmethyldipolyethoxylsilicane (V) were investigated. $\mathrm{V}$ was synthesized from 2-perfluoro-2'-methyl-3'-oxocaproyloxylethyl methacrylate and methyldichlorosilicane by hydrosilication, then by alcoholysis with polyglycol, and was characterized by FTIR and MS. The penetration percentage of diclofenac sodium in different solutions of $2 \%$ 1-menthol, $0.5 \% \mathrm{~V}, 2 \%$ 1-menthol-0.5\% V and $2 \%$ azone were respectively determined with improved Franz equipment and using rat skin as transderma barrier. The enhancement ratios were 3.11, 1.19, 5.46 and 6.21, respectively. $\mathrm{V}$ with 1-menthol could improve the trasdermal amount of diclofenac sodium, especially, but sole $\mathrm{V}$ express bad performance for it.
\end{abstract}

Keywords-component; diclofenac potassium; hydrosilication; enhancement ratios; transdermal velocity; 1-menthol

\section{INTRODUCTION}

Transdermal drug delivery system (TDDS) is a medicine control and release system which promotes the medicine to penetrate the skin and enter the body circle. TDDS is better than taking the medicine by mouth or by injection, for example TDDS can keep away the absorption obstacle of the stomach and intestines caused by the interaction among the enzyme, food, gastric acid or other medicines. Sometimes, it is difficult for medicine to be absorbed because of barrier of skin stratum corneum, especially the macromolecular drugs is absorbed very slowly through skin. So some new transdermal methods, for example physical and pharmaceutics, are developed [1-3]. Penetration enhancers are the first choice to improve transdermal absorption though iontophoresis[4], sonophoresis[5 6], microneedles[7] and thermalphoresis[8] etc. which may cause physiological damage of skin prospect the development. The penetration enhancers are in favor of medicine percutaneous absorption and overcome the barrier of skin stratum corneum mainly by changing the microstructure of stratum cormeum, enhancing lipid flow ability, acting on one or some lipid components and changing protein conformation[9 10].

Penetration enhancers (PE) consist of natural PE and synthesized PE. There are menthol, terpene and alkaloid for main natural PE [11 14] and organic acids and their greases [15 16], azone[17 18], carbamide, dimethyl sulfoxide and its derivatives [19 20], Pyrrolidinone etc. for main synthesized PE. Carbamide can dissolve cutin strongly because of its high concentration (above 40\%), break off skin and be not safe in usage, so is seldom used now. Recently, the United States have forbidden dimethyl sulfoxide because its high concentration could cause erythema, blister and irreversible damage on skin. One of the main defects of synthesized PE is short of specificity, can promote skin to absorb other vehicle components, so that any impurity can be absorbed by the skin and enter the blood circulation. The merits of natural PE are good effect, small side effect and no pollution, but it has slow function and a limited applying scope. It is very important for children to use safely external ointment medicine without toxicity. Human skin is a kind of surface with low energy because there is grease on it. An external ointment medicine can smoothly be spread on the skin and penetrate within the skin only when the surface energy of the ointment containing medicine is lower than that of skin. 2-methyl-2perfluoro-2'-methyl- 3'- oxoca-proyloxyl ethoxycarbonyl ethylmethyldipolyethoxylsilicane (V) was synthesized and $\mathrm{V}$ expressed excellent coordination to promote penetration when it was used with natural PE menthol.

\section{EXPERIMENT}

\section{A. Material}

Karstedt catalyst $\left\{\mathrm{Pt}_{2}\left[\mathrm{Me}_{2}\left(\mathrm{CH}=\mathrm{CH}_{2}\right)_{2} \mathrm{Si}_{2} \mathrm{O}\right], 95 \%\right.$, Taizu New Materials Co., Ltd. \}, 2-perfluoro-2'-methyl-3'oxocaproyloxylethyl methacrylate (I, 99\%, Taizu New Materials Co., Ltd.), methyl dichlorosilane( $99 \%$, Zhejiang Xinan Chemical Industrial Group Co., Ltd.), acetone(AR, Shuanglin Chem. Co., Ltd.), tetrahydrofuran (AR, 
Shuanglin Chem. Co., Ltd.), polyethylene glycol 400(PEG400, CP, Nanjing Chem. Reagent Co., Ltd.). SpragueDawley (SD rat, $80 \pm 5 \mathrm{~g}$, mixt sex, Zhejiang University Lab. Animal Center). Infrared spectrometer(AVATAR 370, Nicolet, USA ), high performance liquid chromatography (Waters 515, Waters, USA ), mass spectrograph(Agilent 6210 LC/TOF), improved Franz diffusion cell(volume and acreage of receptor compartment are $5 \mathrm{~mL}$ and $0.502 \mathrm{~cm}^{2}$ respectively, Beijing Glass instrument Factory). Maintaining the Integrity of the Specifications

The template is used to format your paper and style the text. All margins, column widths, line spaces, and text fonts are prescribed; please do not alter them. You may note peculiarities. For example, the head margin in this template measures proportionately more than is customary. This measurement and others are deliberate, using specifications that anticipate your paper as one part of the entire proceedings, and not as an independent document. Please do not revise any of the current designations.

\section{B. Synthesis of 2-Methyl-2-Perfluoro-2'-Methyl-3'-Oxoca- Proyloxylethoxycar-Bonyl Ethylmethyldipolyethoxylsilicane ( $V)$}

To a $250 \mathrm{~mL}$ four-necked round-bottom flask equipped with a heating water bath, thermometer, dropping funnel, stirrer and reflux condenser, $4.42 \mathrm{~g}(0.01 \mathrm{~mol})$ 2-perfluoro2'-methyl-3'-oxocaproyloxylethyl methacrylate(I), $25 \mathrm{~mL}$ tetrahydrofuran and $0.022 \mathrm{~g}$ acetone solution of $2 \%$ $\mathrm{Pt}_{2}\left(\mathrm{Me}_{2}\left(\mathrm{CH}=\mathrm{CH}_{2}\right)_{2} \mathrm{Si}_{2} \mathrm{O}\right)_{3}$ were added. The mixture was stirred at room temperature for $30 \mathrm{~min} .1 .15 \mathrm{~g}(0.01 \mathrm{~mol})$ methyl dichlorosilane (II) was added dropwisely within 30 min. The mixture was heated to $50^{\circ} \mathrm{C}$ and then stirred for 20 $\mathrm{h}$ at the same temperature to get intermediate (III). The mixture containing III was not separated and was added dropwisely $8.00 \mathrm{~g}(0.02 \mathrm{~mol})$ polyethylene glycol $400(\mathrm{IV})$, and stirred at $50{ }^{\circ} \mathrm{C}$ for $3 \mathrm{~h}$. The reaction was shown in Scheme 1. After the reaction completed, the solvent and other volatile substances were removed by a rotary evaporator under reduced pressure at $50^{\circ} \mathrm{C}$. The residue was extracted with $20 \mathrm{~mL}$ diethyl ether, dried at $105{ }^{\circ} \mathrm{C}$ and $18.28 \mathrm{~g}$ white solid FY1 was obtained in the yield of $91.4 \%$, m.p. $220{ }^{\circ} \mathrm{C}$ (decomposed). After being removing diethyl ether, the extract was dissolved in $20 \mathrm{~mL}$ water. The solution was standing and demixed to separate up-layer which was treated by dehydration to deliver colorless, transparent, sticky liquid (V). IR $(\mathrm{KBr}) \vee\left(\mathrm{cm}^{-1}\right)$ : 3453(OH), 2875(C-H), 1107(C-O-C), 1245, 991 and 746(C-F). ESI-MS $(\mathrm{m} / \mathrm{z}): 1228.8[\mathrm{M}+2 \mathrm{H}]^{+}, 1272.9,1316.8,1361.6,1405.7$.

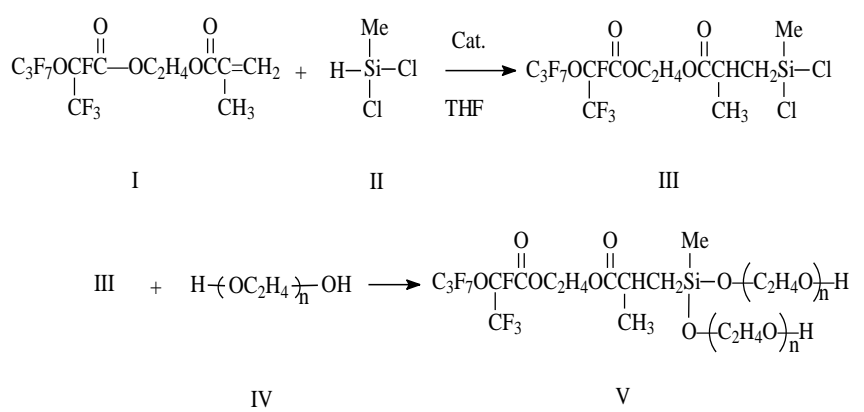

Figure 1. Synthesis of compound V

\section{Preparation of Extracouporeal Mouse Skin}

Ten SD rats were selected randomly from 40 SD rats and were sacrificed by breaking neck. Abdominal hair was removed by a electric razor and hair removal agent-sodium sulfide. The skin was stripped, spread over a glass plate, eliminated the subcutaneous adipose and adhesions carefully, rinsed with normal saline repeatedly and then, cut to proper size. The compete and no damaged skins of rat were immersed in normal saline.

\section{Penetration Test of The Medicine}

Skin stratum corneum of the SD rat was faced toward the supply compartment of the improved Franz diffusion cell and clipped between the supply compartment and the receptor compartment. $0.5 \mathrm{~mL}$ supplied liquid was delivered to the supply compartment and $5 \mathrm{~mL}$ normal saline was delivered to the receptor compartment as receiving solution. The improved Franz diffusion cell was agitated and was put in a constant temperature water bath at $30 \pm 0.5^{\circ} \mathrm{C} .4 \mathrm{~mL}$ obtained solution was taken out in 2, 4, 6, 8 and $12 \mathrm{~h}$ from the receptor compartment, respectively, and another $4 \mathrm{~mL}$ fresh normal saline was immediately delivered into the receptor compartment. The content of the receiving solution was analyzed by a high performance liquid chromatography (HPLC).

\section{E. Analysis of Diclofenac Sodium by HPLC}

The chromatographic column: Kromasil C18 column(250 $\mathrm{mm} \times 4.6 \mathrm{~mm}, 5 \mu \mathrm{m}$,Tianjin FLM Technology Co., Ltd.); mobile phase: $0.025 \mathrm{~mol} \cdot \mathrm{L}^{-1}$ phosphoric acid solution $(\mathrm{pH}$ $3.0 \pm 0.05$, regulated with triethyl amine )-acetonitrile (V Phosphoric acid solution: $\mathrm{V}$ acetonitrile); detection wavelength: $276 \mathrm{~nm}$; current speed: $1.0 \mathrm{~mL} / \mathrm{min}$; sample volume: $20 \mu \mathrm{L}$. Linear regression for peak area $(\mathrm{Y})$ to mass concentration $(\mathrm{X})$ get regression equation $\mathrm{Y}=26103.9 \mathrm{X}+$ $19981.5, \mathrm{r}=0.9996$, linear range was $30 \sim 300 \mu \mathrm{g} / \mathrm{mL}$.

\section{F. Preparation of The Supplied Liquid}

Diclofenac sodium was dissolved in $95 \%$ ethanol to give $1.25 \%(\mathrm{w} / \mathrm{v}$, the same below ) diclofenac sodium solution by which some release solutions were prepared : sample 1: containing no penetration enhancer; sample 2: containing $2 \%$ menthol; sample 3: containing $0.5 \% \mathrm{~V}$; sample 4 : containing $2 \%$ menthol- $0.5 \% \mathrm{~V}$; sample 5: containing $2 \%$ azone. 


\section{G. Accumulated Transmission Volume of Diclofenac Sodium}

The accumulated transmission volume of diclofenac sodium (Q) was get by formula (1)

$$
\mathrm{Q}\left(\mu_{\mathrm{g}} / \mathrm{cm}^{2}\right)=\frac{\mathrm{Cn} \times 5+\Sigma_{\mathrm{Ci}} \times 4}{\mathrm{~A}}
$$

In which $\mathrm{Cn}$ was the medicine concentration of the $\mathrm{n}$-th sampling point $\left(\mu \mathrm{g} \cdot \mathrm{mL}^{-1}\right), \mathrm{Ci}$ was the medicine concentration of the i-th sampling point $\left(\mu \mathrm{g} \cdot \mathrm{mL}^{-1}\right), \mathrm{A}$ was the diffusion area $\left(\mathrm{cm}^{2}\right)$.

Linear regression fitting of time $\mathrm{T}$ by using $\mathrm{Q}$ get a linear equation, the gradient of which was the transdermal drug delivery rate $\mathrm{P}$. If the contrast solution penetration rate is $\mathrm{P} 0$, then the $\mathrm{P} / \mathrm{P} 0$ is the enhancement ratio

\section{RESULTS AND DISCUSSION}

\section{A. Chemical Structure Characterization of $V$}

There is no $\mathrm{H}-\mathrm{Si}$ stretching vibration absorption peak $\left(2146 \mathrm{~cm}^{-1}\right)$ in the infrared spectra of target compounds V which indicated that all methyldichlorosilane had transformed. $3453 \mathrm{~cm}^{-1}$ was for $\mathrm{H}-\mathrm{O}$ stretching vibration absorption peak; $2875 \mathrm{~cm}^{-1}$ was for the $\mathrm{H}-\mathrm{C}$ stretching vibration peak; $1107 \mathrm{~cm}^{-1}$ was for the O-C stretching vibration peak; $1245 \mathrm{~cm}^{-1}$ was for the $\mathrm{F}-\mathrm{C}$ stretching vibration absorption peak; 991 and $746 \mathrm{~cm}^{-1}$ was for F-C flexural vibration absorption peak. Polyethylene glycol -400 (PEG-400, IV) is a mixture, the average molecular weight of PEG-400 is 400, so the product $\mathrm{V}$ is also a mixture, and each compound has a difference of one $\left(-\mathrm{CH}_{2} \mathrm{CH}_{2} \mathrm{O}-, \mathrm{M}=44\right)$ fragment; The molecular weight of compound $\mathrm{V}$ is 1226 , the corresponding peak in the ESI-MS spectrum is $1228.8[\mathrm{M}+2 \mathrm{H}]+$, and the difference between the other two peaks is about 44 . Based on the above analysis, the results of the reaction can be determined, and the product of the reaction is $\mathrm{V}$.

\section{B. Effect of Different Penetration Enhancer on The Transdermal Drug Delivery}

The menthol, compound V, menthol - compound V and azone were selected as penetration enhancers, the effects of which on in vitro transdermal drug delivery rate $\mathrm{P}$ and the enhancement ratio $\mathrm{P} / \mathrm{P}_{0}$ were investigated as shown in Table 1 below. From Table 1, we got that $2 \%$ menthol has better effect on the penetration of diclofenac sodium, the enhancement ratio $\mathrm{P} / \mathrm{P}_{0}$ was 3.11 , while the effect of the promotion of the $0.5 \%$ compound $\mathrm{V}$ was not significant, $\mathrm{P} / \mathrm{P}_{0}$ was only 1.19 . But the $2 \%$ menthol $-0.5 \% \mathrm{~V}$ can enhance skin penetration rate reached $181.462 \mu \mathrm{g} /\left(\mathrm{cm}^{2} \cdot \mathrm{h}\right), \mathrm{P} / \mathrm{P}_{0}$ was as high as 6.24, exceed the enhancement ratio of $2 \%$ azone on diclofenac sodium (5.46). This shows that fluorine silicone surfactant synthesized, when used alone, had little effect on percutaneous penetration of diclofenac sodium. But with the use of natural penetrant, menthol, its effect is greatly increased and can replace azone.
TABLE I. EFFECT OF DiFFERENT PENETRATION ENHANCER ON THE TRANSDERMAL DRUG DELIVERY

\begin{tabular}{|c|c|c|c|c|}
\hline Sample & PE & $\begin{array}{c}\text { Sample } \\
\text { size }\end{array}$ & $\mathrm{P} \mu \mathrm{g} /\left(\mathrm{cm}^{2} \cdot \mathrm{h}\right)$ & $\mathrm{P} / \mathrm{P}_{0}$ \\
\hline 1 & Blank & 7 & $29.221 \pm 3.16$ & \\
\hline 2 & $2 \%$ menthol & 6 & $90.920 \pm 4.75^{*}$ & 3.11 \\
\hline 3 & $0.5 \% \mathrm{~V}$ & 6 & $34.791 \pm 5.39 *$ & 1.19 \\
\hline 4 & $2 \%$ azone & 6 & $181.462 \pm 6.32 *$ & 5.46 \\
\hline 5 & $\begin{array}{c}2 \% \text { menthol- } \\
0.5 \% \mathrm{~V}\end{array}$ & 6 & $159.547 \pm 2.49 *$ & 6.21 \\
\hline
\end{tabular}

\section{CONCLUSIONS}

2-Methyl-2-perfluoro-2'-methyl-3'-oxoca-proyloxyletho-xycarbonylethylmethyl dipolyethoxylsilicane (V) was synt-hesized by hydrosilylation from 2-perfluoro- 2'- methyl-3'oxocaproyloxylethyl methacrylate(I) and methyl dichlorosi--lane(II), then by alcoholysis with polyglycol, and was characterized by FTIR and MS. The penetration percentage of diclofenac sodium in different solutions of $2 \% 1$-menthol, $0.5 \% \mathrm{~V}, 2 \%$ azone and 2\% 1-menthol- $0.5 \% \mathrm{~V}$ were determined respectively. The enhancement ratio were 3.11, $1.19,6.21$ and 5.46, respectively. Especially, V with 1menthol could improve the trasdermal amount of diclofenac sodium.

\section{ACKNOWLEDGMENT}

This work was supported by the Research Fund of the Department of Science and Technology of Zhejiang Province (№ 2011R09002-10).

\section{REFERENCES}

[1] Wang CX, Liu YL. New development of transdemal drug delivery system[J]. Acta Pharmaceutica Sinica 2002, 37(12): 999-1002.

[2] Ghulaxe C, Verma R. A review on transdermal drug delivery system[J]. The Pharma Innovation Journal, 2015, 9(1): 37-43.

[3] Marwah H, Garg T, Goyal A K, et al. Permeation enhancer strategies in transdermal drug delivery[J]. Drug delivery, 2016, 23(2): 564-578.

[4] Jaskari T, Vuorio M, Kontturi K, et al. Controlled transdermal iontophoresis by ion-exchange fiber [J]. J Controlled Release, 2000, 67(2-3):179-190.

[5] Mitragotri S, Farrell J, Tang H, et al .Determination of threshold energy dose for ultrasound- induced transdermal drug transport $[\mathrm{J}] . J$ Controlled Release, 2000, 63(1-2):41-52.

[6] Zorec B, Jelenc J, Miklavičič D, et al. Ultrasound and electric pulses for transdermal drug delivery enhancement: Ex vivo assessment of methods with in vivo oriented experimental protocols[J]. International journal of pharmaceutics, 2015, 490(1): 65-73.

[7] Henry S, Mcallister D, Allen M , et al. Microfabricated microneedles:a novel approach to transdermal drug delivery $[\mathrm{J}] . J$ Pharm Sci, 1998, 87(8):922-925.

[8] KUMARKS, LINCOLNDF, EPPSTEINJA, etal. Lightbeam generation, and focusing and redirecting device. US, 6951411[P]. 2005-10-04.

[9] Sun YQ, Chen XY, Zhou LL. Progress of transdermal drug delivery system [J]. J. Anhui TC M College, 2001,20(3):62-63. 
[10] Ita K B. Transdermal drug delivery: progress and challenges[J]. Journal of Drug Delivery Science and Technology, 2014, 24(3): 245250.

[11] Namba T, Sekiya K, Kadota S, et al. Studies on the baths with crude drug: the effects of Senkyu ex tracts as skin penetration enhancer[J] .Yakugaku Zasshi, 1992, 112(9):638-644.

[12] Aqil M, Ahad A, Ali A, et al. Status of terpenes as skin penetrationen hankers[J]. Drug Discovery Today, 2007, 12(23-24):1061-1067.

[13] Fujii M, Takeda Y, Yoshida M, et al. Enhancement effect of pmenthane-3, 8-diol on invitropermeation of antipyrine and indomethacine through yucatan micropig skin[J]. Drug Dev Ind Pharm, 2004, 30(6):673 -677.

[14] Patil U K, Saraogi R. Natural products as potential drug permeation enhancer in transdermal drug delivery system[J]. Archives of dermatological research, 2014, 306(5): 419-426.

[15] Okumuar M, Sugibayashi K, Moirmoto Y, et al. Effect of several enhancers on the skin perme ation of water-soluble drugs [J]. Chem Pharm Bull, 1989,7(5): 1375-1377.
[16] Pawar V, Naik P, Giridhar R, et al. Enhancing Skin Permeation of Biphenylacetic Acid (BPA) Using Salt Formation with Organic and Alkali Metal Bases[J]. Scientia pharmaceutica, 2015, 83(1): 191-205.

[17] YUAN ZT, CHEN DW, DING PT, et al. Effect of azo neon permeation of $\mathrm{O} s$ thol through skin in vitro $[\mathrm{J}]$. Pharm J Chin PLA, 2004, 20(1):37-39.

[18] Williams A C, Barry B W. Penetration enhancers[J]. Advanced drug delivery reviews, 2012, 64: 128-137.

[19] Song Y, Xiao C, Mendelsohn R, et al. Investigation of iminosulfuranes as novel transdernal penetration enhancers: enhancement activity and cytotoxicity[J]. Pharm Res, 2005, 22(11):1918 -1925.

[20] Saffari M, Tamaddon A M, Shirazi F H, et al. Improving cellular uptake and in vivo tumor suppression efficacy of liposomal oligonucleotides by urea as a chemical penetration enhancer[J]. The journal of gene medicine, 2013, 15(1): 12-19. 